\title{
Strategic Implementation of Speech Functions on the Automotive Billboard Texts
}

\author{
Muhammad Hasyimsyah Batubara \\ State Institute of Islamic Studies Takengon, Aceh Tengah, Aceh, 24552, Indonesia \\ E-mail: muhammad.hasyimsyahbatubara@gmail.com
}

\begin{abstract}
This research aims to describe the category and derive dominantly used speech functions in the automotive billboard texts. The study used a descriptive qualitative method. Data is automotive billboard texts around the Medan city, and it is collected by applying documentary techniques. The finding describes there are three speech functions available used in automotive billboard texts. They are ten statements $(76.9 \%)$, one offer $(7.7 \%)$, and two commands $(15.4 \%)$, and there is no question in this domain. The statement model used as the stand-out one is compatible with the essential functions of commercial billboard texts, the viewer estimated only concisely saw the images and display of the billboard texts with 5-7 seconds when they were driving. Hence, the power of speech function and the language used must be effective, efficient, and capable of persuading or hypnotizing readers to take consumptive actions against products advertised by manufacturers.
\end{abstract}

Keywords-Automotive; Billboards Texts; Speech Functions

Manuscipt received 25 Sept. 2020; Revised 23 Feb. 2021 ; Accepted 28 Mar. 2021

\section{INTRODUCTION}

In today's era of easy access to information, language has a crucial role in presenting the correct information to listeners. The existing information media, both digital and visual media, help people or community groups convey their thoughts, ideas, invitations, and information. The function of language is a strategy in providing a descriptive and interpretive framework for communication. Language resources are not only limited to linguistic meanings but also associated with meanings related to various aspects of social systems in society, and it is known as language metafunctions.

In language metafunctions, functions are grouped into three parts: ideational functions, interpersonal and textual functions. On this occasion, the study was only on interpersonal functions because of the tendencies seen in society. Understanding interpersonal functions hope that developing social relationships will be better in interacting with other community members. The process of understanding a speaker's speech through interpersonal functions can be done by approaching the speech function (statements, questions, offers, orders). The four speech functions will directly help listeners or viewers receive the meaning of a single statement or utterance in a communication interaction.

Many areas can be the research object on speech functions, but this research focuses on billboards areas. It is a form of

communication media, offers extraordinary promises about advertisers' products to consumers through informative and persuasive messages. The interesting thing to research about billboard text is how the language that is made is compelling to influence the audience's mind only using little words, which are sometimes arranged not according to grammar. Further, as an outdoor advertising medium with a large size placed in strategic and crowded areas and places, it positively influences promotional propaganda. Based on the above considerations, this study aims to see the tendency of strategic application of speech function language on automotive billboards in the marketing process of high-quality products to attract public attention.

\section{A. Speech Functions}

Speech function is a performance or action by language users in the form of a statement, question, offer, and command (Grolier, 1992; Gerot, 1994; Morley, 2000). It is applied to exchange the experience between speakers and listeners in reserve to comply with their requirements. Furthermore, A statement is a process of providing information in either a positive or negative pattern. It is named a statement if the subject is positioned in front of a verb or auxiliary verb. Then, it is ended with a period (.) (Cobuild, 2011; Leech, 2003; Carter, 2006; Downing and Locke, 2006; in Batubara and Nasution, 2020; 2020a; 2020b). In other words, statement form is a declarative or assertive statement intended to provide information in spoken or written language.

A question form is a process of demanding information within the scheme of interrogative expression, which inquires 
reply from the listener (Grolier, 1992; Cobuild, 2011; Leech, 2003; Carter, 2006; Downing and Locke, 2006; in Batubara and Nasution, 2020; 2020a; 2020b). There are three types of questions, such as: (1). Yes/no question can answer with a "yes" or "no". (2.) Wh-question uses an interrogative word to ask for information. The question words are who, what, when, where, why, how, which are usually end with a question mark (?). In further, they cannot be answered only with yes or no but with meaningful information. (3.) Tag questions are a grammatical structure form in which a declarative or a binding fragment (the 'tag"), such as 'right, don't you, doesn't he?. For example, is "He still calls his mother, doesn't he?" The tag question can be answered only with two possible answers, namely yes or no.

An offer is a process of giving goods and services to someone. According to Collins (1998) stated an offer began to attach one of the modals, then added by a subject and terminated with a question mark (?). An offer form is also interpreted as an expression of willingness to give or continue something for acceptance or rejection (Grolier, 1992).

A command is a process of expecting goods and services in the scheme imperative, and maybe the shape is a positive or negative command. Further, in the command sentence, the subject is omitted, and the primary form of verbs is used (Collins, 1998). Alternatively, it begins by the predicate and is generally terminated with an exclamation mark (!).

For examples between initiation and responding speech functions are:

TABEL I

INITIATION AND RESPONDING SPEECH FUNCTIONS

\begin{tabular}{|l|l|}
\hline \multicolumn{1}{|c|}{ Speaker: } & $\begin{array}{c}\text { Listener (becoming speaker in his } \\
\text { turn): }\end{array}$ \\
\hline Statement & Acknowledgment Statement \\
\hline He is buying a car. & $\begin{array}{c}\text { Oh, is he. Yes, he is. No, he is } \\
\text { not. }\end{array}$ \\
\hline Question & Response Statement to Question \\
\hline $\begin{array}{l}\text { What is she } \\
\text { buying? }\end{array}$ & A car or I do not know \\
\hline $\begin{array}{l}\text { Offer } \\
\text { Would you like to }\end{array}$ & Yes, I would. No, I would not. \\
\hline Command & Response Offer to Command \\
\hline \begin{tabular}{l} 
Listen to me! \\
\hline
\end{tabular} & All right, I will. No, I will not. \\
\hline
\end{tabular}

In switching to speakers, listeners have substantial discretion. He can give different answers to anyone in response to a question and carry out an order differently. On the other hand, he can also refuse to answer the question altogether or reject the orders he hears and reads. The previous explanation concludes that speech function recognizes a correlation between the different structures of an initiating move and responding move, either positive or negative, responding speech functions.

\section{B. Billboard}

Billboard is known as outdoor advertising or outdoor sign and poster, usually seen on busy streets, highways, and freeways. Furthermore, the billboard is widely using in advertising communication related to non-profit causes, product marketing, and political campaigns. There are four billboards: conservative billboards, mechanical billboards, and recently developed types are digital and mobile billboards (Filiquarian, 2008). It is one of the choices of time lately because it offers a lower budget than advertising on TV, but it is adequate to advertise products to increase. It is supported by research conducted by Hussain and R. K. N. (2011); Chopra (2017); Dhesi (2018); Herrera and Pasch (2018) in Batubara and Nasution (2020); (2020a); (2020b), conveying that billboards are beneficial advertising media in introducing products amid other advertising media.

\section{METHOD}

This research project is a qualitative descriptive method. Bogdan and Biklen (1992) explained that the qualitative approach is identical to descriptive. This study aims to find out what categories of speech function is used in commercial billboard texts and why it is used dominantly in the commercial billboard texts. The source of data source taken in this research is the commercial billboard texts placing in the busiest streets in Medan. Meanwhile, the sample is only the commercial billboard texts in the automotive advertisement. Therefore, the data gathered as the sample is only ten percent (13) from the total number of automotive billboard texts is 130. Arikunto (2006); Moleong (2020) stated that the sample is a part or representative of the population studied.

Data collection is through documentary techniques covering the following steps. First, the automotive billboards texts are identified and located explicitly at the busiest streets or middle up societies in Medan. Second, the data are recorded or captured in both texts and pictures of automotive billboards, and finally, the data transcribed by printing them out. The technique applied is a descriptive analysis to draw speech function in automotive billboard texts in analyzing the data. According to Miles and Huberman (1984) in Batubara and Mahardhika (2020) stated that the data would be analyzed through four actions: data collection, reduction of data, display of data, and conclusions.

\section{RESULT AND DISCUSSION}

\section{A. Types of Speech Functions in Automotive}

After collecting the data, it was classified as the general automotive billboard based on the speech functions, whether it is a statement, question, offer, and command from the whole commercial billboard text. There were thirteen sentences used in this research as the proportion of texts as the data sources data from the automotive billboard texts. Then all the sentences were classified one by one, and both the type used and the most dominant one are gathered from the data. Table 2 inform about the data analyzed in the automotive billboard texts. From the thirteen commercial billboard texts, it is found that there is no question speech function, but there are three other speech functions found in automotive billboard texts. They are a statement, offer, and command. In more detail, the statement found is ten, the offer found is one, and the command found is two. Further, the propositions of speech functions were included in the table. 
TABLE 2

TYPES OF SPEECH FUNCTIONS IN AUTOMOTIVES

\begin{tabular}{|c|l|c|c|}
\hline No & $\begin{array}{c}\text { Types of } \\
\text { Speech }\end{array}$ & $\begin{array}{c}\text { Number of Speech } \\
\text { functions }\end{array}$ & Percentage \\
\hline 1. & Statement & 10 & $76.9 \%$ \\
\hline 2. & Question & 0 & 0 \\
\hline 3. & Offer & 1 & $7.7 \%$ \\
\hline 4. & Command & 2 & $15.4 \%$ \\
\hline & Total & $\mathbf{1 3}$ & $\mathbf{1 0 0 \%}$ \\
\hline
\end{tabular}

\section{Statements}

The statement is the most dominantly used from the whole speech functions used in the automotive billboard texts. It is less effective if the company of automotive used statement speech function such as:

(1.) A perfect arrangement (Toyota Avanza)

(2.) Ertiga the inner excitement for every journey! (Suzuki Ertiga)

Sentences 1 and 2 show the high cost, which makes the product difficult to sell so that the speech function in a statement is less useful in this case. Moreover, it is not as the daily need to buy it due to continuing this life. Then, Baack (2007) stated that automotive is one of the luxurious things besides yachts and vacation at a luxury resort with high-cost goods and services. Therefore, car product marketers should work closely with creative creators to tailor messages to different layers of income groups and select media that fits that group. Because if it is not supported by acceptable advertising language, it will be sure that the existing automotive products will be challenging to sell.

\section{Command}

(3.) Rainbow Your Life (Mitsubishi MIRAGE)

(4.) Go get it (SUZUKI Mini MPV)

Sentences 3 and 4 show speech function used in automotive billboard texts is a command. It happens because the command is close to the statement. The difference is only the way of expressing it, which is less impolite. Thus, when many companies consider using statements to claim that their product is the best among others, the emergence of command is thought of as an alternative to influence the viewers' mind in consuming something with a clear direction. Moreover, its emergence is suited to the basic concept of an advertisement on commercial billboard texts in which the text must be as simple as possible.

\section{Offer}

In further, the offer speech function is a more suitable one to be used in automotive advertising. By using the offer speech function, the company has a large area to explain the strength of its product, such as:

(5.) "Installment 2.8 Installment Period 3 Years 25\% down payment" (Toyota Yaris)

Sentence 5 shows that the viewers will calculate their product's advantages as their consideration before buying the automotive product. It means that offering is a crucial point to influence the viewers in automotive advertising. Meanwhile, the fact is not as what is stated theoretically. It is known that statement is the most dominant speech function found in automotive billboard texts. There is a principal reason why the company briefly decides to use a statement in this case. The company firmly keeps the concept of billboard texts, which are read by viewers only in five to seven seconds, so that the language used must be handy and efficient with little words. It is different from the automotive advertisement in a newspaper, which is in one line with the theoretical. In the newspaper, automotive advertising uses offer speech function commonly used because viewers' time in the reading newspaper is not as fast as viewers' time reading billboard texts. Also, Baack (2007) uttered that the direct advantage placed ads in newspapers and on the radio focuses on the 'value' an individual could obtain by trading down or across. In the newspaper, it still uses offer speech function as what is found in theory.

\section{B. Discussion}

First of all, there 13 commercial billboard texts taken by the researcher as the objects of this study. Then, based on data analysis done on the 13 texts at the previous, it is known that there are only three speech functions used in automotive billboard texts. They are ten statements (76. 9\%), one offer (7. $7 \%$ ), and two commands (15. 4\%), and there is no question form in this domain.

The statement is used dominantly in this domain because it symbolizes an exact sentence with muscular stress to be remembered. It is eligible for the soul of men that prefer to say something less but do many things. According to Lane, et al (2005) stated that many famous advertisements in this world prove the strength of the statement.

Meanwhile, offer and command are also used, but it is not very significant because it is just an alternative way of varying the language on the commercial billboard texts. It is strengthened by Alstiel and Grow (2007) in their book entitled Advertising Strategy. In that book, it is stated that sometimes you can set up a concept in a modified question or answer format, where the question (or problem) is stated, and the product, package, a logo is the answer.

In contrast, the question is not used because it symbolizes an unclear emphasis or doubtful confidence, which contradicts men's souls. It means that it is the last alternative used in making commercial billboard texts because it is thought of as the ineffective speech function in hypnotizing the brand in the viewer's mind. It is further realized that basically, there has been a question in their mind about "which brand of shall they buy for fulfilling their need?" (Lane, et al,. 2005). Thus, when the language in billboard texts is also given in question form, there will be double questions in the viewers' minds that make them forget one of them. That is why many companies attempt to ignore the existence of question speech function in commercial billboard texts.

\section{IV.CONCLUSIONS}

Conclusions of strategic implementation of speech functions on the automotive billboard texts are down as the following:

1. In general, there are three speech functions found in automotive billboard texts. They are statement consists of 10 , command with the number 2 , and offer used in 1 text.

2. There is no speech function found in question form in automotive billboards. 
3. The most dominant type of speech function used in the automotive billboard texts is a statement.

4. In commercial billboard texts, a statement is using because billboard texts are advertisements placed on a busy street in which the massage billboard texts must touch people only in 5-7 seconds. Thus, the language used must be as effective as possible. The most effective way to inform a product is by using a statement because of its ability to give information, to declare something in a short time, and to persuade viewers even only in a few seconds.

\section{REFERENCES}

A. L. Herrera \& K. E. Pasch. (2018). Targeting Hispanic adolescents with outdoor food \& beverage advertising around schools. Journal of Ethnicity \& Health, 23(6), 691-702. $10.1080 / 13557858.2017 .1290217$

Alstiel, T. and Grow, J. (2007). Advertising Strategy. Singapore: Seng Lee Press.

Arikunto, S. (2006). Prosedure Penelitian Suatu Pendekatan Praktek. Jakarta: Rineka Cipta.

Baack, C. (2007). Integrated Advertising, Promotion and marketing Promotion (3rd ed.). New Delhi: Pearson Education.

Batubara, M. H., \& Mahardhika, M. G. S. (2020). An Analysis On Students' Difficulties In Changing Active To Passive Voice. Jurnal As-Salam, 4(1), 61-78. https://doi.org/https://doi.org/10.37249/assalam.v4i1.175

Batubara, Muhammad Hasyimsyah, Nasution, D. S. (2020). The Dominant Speech Functions in Cigarette Billboard Texts. JELTL (Journal of English Language Teaching and Linguistics), 5(2), 177-189. https://doi.org/http://dx.doi.org/10.21462/jeltl.v5i2.407

Batubara, M. H. (2020a). An Analysis Of Speech Functions On The Banking And Daily Need Billboard Texts. International Journal of Humanity Studies (IJHS), 4(1), 110-121. https://doi.org/http://dx.doi.org/10.24071/ijhs.v4i1.2816

Batubara, M. H. (2020b). An Analysis of Speech Functions Realizations on the Electronics and Furniture Billboard Texts. Jurnal Ilmu Komunikasi, 18(3), 303-311. https://doi.org/https://doi.org/10.31315/jik.v18i3.3563

Bogdan, R.C. and Biklen, K. S. (1992). Qualitative Research for Education: An Introduction to Theory and Methods. Boston: Allyn and Bacon.

Carter, R. and M. M. (2006). Cambridge Grammar Of English A Comprehensive Guide Spoken and Written English Grammar and Usage. Cambridge: Cambridge University Press.

Chopra, G. (2017). A Study on the Relationship Between Customer Attention and Billboards Advertising with Special Reference to Consumer. IOSR Journal of Humanities and Social Science (LOSR-JHSS), 22(11), 63-69. https://doi.org/DOI: 10.9790/0837-2211136369

Cobuild, C. (2011). English Grammar. Glasgow: Harper Collins Publishers.

Collins, P. (1998). English Grammar. South Melbourne: Longman.

Dhesi, D. (2018). The Uptrend of Outdoor Advertising. Retrieved July 9, 2020, from Malaysia: Star Media
Group

Berhad website: https://www.thestar.com.my/business/businessnews/2018/06/02/the-uptrend-of-outdoor-advertising/

Downing, Angela and Locke, P. (2006). English Grammar A University Course (Second Edi). USA and Canada: Routledge.

Filiquarian. (2008). Advertising-for- Know-it-alls. USA: Filiquarian Publising LLC.

Gerot, L. and P. W. (1994). Making Sense of Functional Grammar an Introducing Workbook. Sidney: GerdStabler.

Grolier, A. (1992). New Webster's Dictionary. Connecticut: Grolier Inc.

Hussain, J. \& R. K. N. (2011). Factors Affecting Consumer Attention in Billboards Advertising. South Asian Journal of Management Sciences, 5(2), 60-64. Retrieved from https://econpapers.repec.org/article/ajmjournl/v_3a5_3a y_3a2011_3ai_3a2_3ap_3a60-64.htm

Lane Rolan W, K. W. K. and R. T. J. (2005). Advertising Procedure (Sexteenth). New Delhi: Pearson Education.

Leech, G. and J. S. (2003). A Communicative Grammar of English (3rd Editio). London: Routledge.

Miles, Matthew. B \& Huberman, M. A. (1984). Qualitative Data Analysis. London: Sage Publication, Inc.

Moleong, L. J. (2020). Metodologi Penelitian Kualitatif (Edisi Revi). Bandung: Remaja Rosdakarya.

Morley, G. D. (2000). An Introduction to Systemic Grammar. Hong Kong: Macmillan. 